\title{
PEMANFAATAN SERBUK KACA SEBAGAI BAHAN TAMBAH DALAM PEMBUATAN BATAKO
}

\section{Use of Materials as Glass Powder Added In Making Batako}

\author{
Nursyamsi ${ }^{1}$, Ivan Indrawan ${ }^{2}$, Ika Puji Hastuty ${ }^{3}$ \\ ${ }^{1}$ Departemen Teknik Sipil Universitas Sumatera Utara \\ email: nursyamsi@usu.ac.id \\ ${ }^{2}$ Departemen Teknik Sipil Universitas Sumatera Utara \\ email: ivanindrawan76@gmail.com \\ ${ }^{3}$ Departemen Teknik Sipil Universitas Sumatera Utara \\ email: ikapuji@gmail.com
}

\begin{abstract}
The increase needed for adobe bricks as substitute for lead in demand for cement as brickforming material. Innovation needed to reduce used, by glass powder. The initial idea that the silica (SiO2) on glass some of which are as same as in cement.. This study uses glass powder as substitute against the weight of cement. Glass powder used consisted of two types glass powder passes sieve No. 100 retained on No.200 (BSKф100-ф200) and glass powder escaped sieve No. 200 (BSK <ф200) with six kinds of mixed composition of 0\%, 10\%, 15\%, 20\%, 25\% and 30\%. Analysis of data by using provisions of SNI 03-0349-1989. The results showed entire BSK qualify for water absorption solid concrete brick quality I by SNI 03-0349-1989. Visual examination showed BSK surfaces have angled, flat, and free from cracks. BSKO\% compressive strength of $95,289 \mathrm{~kg} / \mathrm{cm} 2$ and the compressive strength is highest in BSK $<\phi 200 \_20 \%$ of $91,422 \mathrm{~kg} / \mathrm{cm} 2$ and the quality I belong to the SNI 03-0349-1989. Tensile strength BSK0\% of 16,268kg / cm2 and tensile strength is highest on- $\phi 200 \mathrm{BSK} \phi 100$ percentage of $15 \%$ of $19,464 \mathrm{~kg} / \mathrm{cm} 2$. Overall it is known that BSK $<\phi 200$ with $20 \%$ is the best percentage to be applied next.
\end{abstract}

Keywords: brick; Glass powder; Compressive Strength; strong Pull

\begin{abstract}
Abstrak
Meningkatnya kebutuhan batako sebagai pengganti batu bata mengakibatkan peningkatan kebutuhan semen sebagai bahan pembentuk batako. Sehingga perlu dilakukan inovasi untuk mengurangi pemakaiannya dengan menggunakan serbuk kaca. Gagasan awal pemikiran bahwa silika ( $\mathrm{SiO} 2)$ yang ada pada kaca sama seperti yang ada pada semen. Penelitian ini menggunakan serbuk kaca sebagai bahan subtitusi terhadap dari berat semen. Serbuk kaca yang digunakan terdiri dari dua jenis yaitu serbuk kaca lolos ayakan No. 100 tertahan pada ayakan No.200 (BSKø100- $\varnothing 200)$ dan serbuk kaca lolos ayakan No. 200 (BSK<ø200) dengan 6 macam komposisi campuran $0 \%, 10 \%, 15 \%, 20 \%, 25 \%$, dan 30\%. Analisis data dengan menggunakan ketentuan SNI 03-0349-1989. Hasil penelitian menunjukkan seluruh BSK memenuhi syarat untuk penyerapan air bata beton pejal mutu I menurut SNI 03-0349-1989. Pengujian visual menunjukkan BSK memiliki permukaan yang siku, rata, dan tidak retak. Kuat tekan BSK0\% sebesar $95,289 \mathrm{~kg} / \mathrm{cm}^{2}$ dan kuat tekan tertinggi terdapat pada BSK<ø200_20\% sebesar $91,422 \mathrm{~kg} / \mathrm{cm}^{2}$ dan tergolong dalam mutu I SNI 03-0349-1989. Kuat tarik BSK0\% sebesar $16,268 \mathrm{~kg} / \mathrm{cm}^{2}$ dan kuat tarik tertinggi terdapat pada BSK $\emptyset 100-\varnothing 200$ persentase $15 \%$ sebesar $19,464 \mathrm{~kg} / \mathrm{cm}^{2}$. Secara keseluruhan diketahui bahwa BSK $<\varnothing 200$ persentse $20 \%$ merupakan persentase paling baik untuk diaplikasikan selanjutnya.
\end{abstract}

Kata-kata kunci: Batako, Serbuk Kaca, Kuat Tekan, Kuat Tarik

\section{PENDAHULUAN}

Batako merupakan salah satu alternatif bahan dinding yaang murah dan relatif kuat. Batako terbuat dari campuran pasir, semen dan air yang dipress dengan ukuran standard. Sejalan dengan pesatnya pembangunan perumahan, maka sangat jelas kebutuhan untuk bahan bangunan akan semakin meningkat. Masyarakat pada umumnya lebih memilih menggunakan batu bata daripada menggunakan batako sebagai bahan bangunan. Namun pada akhirnya kebutuhan akan batako juga mengalami peningkatan yang signifikan. Batako pada saat ini semakin populer digunakan sebagai pengganti batu 
bata merah. Hal ini di sebabkan karena batako di nilai lebih cepat dalam pembuatan maupun pengerjaannya untuk pasang dinding. Dalam pembuatan batako tidak memerlukan proses pembakaran seperti pembuatan batu bata merah. Maka secara tidak langsung kebutuhan batako akan meningkat seiring dengan majunya pembangunan perumahan.

Batako termasuk bahan penyusun dinding yang bersifat non struktural. Meskipun sifatnya hanya bagian non struktural dari bangunan bukan berarti batako tidak memiliki standar kekuatan dan toleransi yang harus dipenuhi, karena dalam penggunaannya batako dengan mutu tertentu dapat dipakai dalam konstruksi yang memikul beban. Terdapat batasan-batasan tertentu sebagai persyaratan pada batako agar dalam penggunaannya, batako memiliki ketahanan dari berbagai macam pengaruh baik pengaruh secara langsung ataupun tidak langsung seperti ketentuan di dalam Standar Nasional Indonesia (SNI 03-0349-1989).

Semakin banyaknya permintaan batako di pasaran akan meningkatkan kebutuhan bahan baku utama konstruksi, salah satunya adalah semen. Dengan meningkatnya kebutuhan akan semen, maka harga semen pun akan semakin tinggi. Ini tentu menjadi satu masalah, terutama di daerah-daerah yang tidak terdapat sumber bahan baku semen. Sehingga tidak heran harga semen di daerah tersebut sangat mahal. Hal ini terus memicu para ahli teknik untuk mengembangkan suatu bahan yang dapat menggantikan atau mengurangi kebutuhan dari salah satu bahan konstruksi tersebut untuk mengurangi biaya bahan baku tanpa mengurangi kualitas hasil. Salah satu bahan alternatif yang dapat digunakan untuk mengganti sebagian semen adalah serbuk kaca sebagai bahan tambah pada batako. Gagasan awal berpedoman pada pemikiran bahwa unsur-unsur kimia yang ada pada kaca sebagian diantaranya sama seperti yang ada pada semen, sehingga apabila kaca dihancurkan menjadi serbuk berkemungkinan berfungsi sebagai filler karena persentase kandungan silika $\left(\mathrm{SiO}_{2}\right), \mathrm{Na}_{2} \mathrm{O}$ dan $\mathrm{CaO}$ pada kaca yang cukup besar yaitu lebih dari $70 \%$ (Karwur dkk, 2013).

Dalam penelitian ini, serbuk kaca digunakan sebagai bahan subtitusi terhadap semen. Dilihat dari kesamaan komposisi kimia dari semen dan serbuk kaca, dapat diasumsikan bahwa serbuk kaca dapat digunakan sebagai bahan pengganti semen. Diharapkan dengan penambahan serbuk kaca dapat mengurangi penggunaan semen dan menghasilkan nilai yang lebih ekonomis. Seperti terdapat dalam Tabel Unsur Semen Portland (Mulyono,2005) dan Tabel Unsur Serbuk Kaca (Lab. MIPA Kimia USU).

\begin{tabular}{|c|c|}
\hline \multicolumn{2}{|c|}{$\begin{array}{l}\text { Tabel } 1 \text { Unsu } \\
\text { Semen Portland }\end{array}$} \\
\hline Unsur & $\begin{array}{l}\text { Semen } \\
\text { Portland }\end{array}$ \\
\hline $\mathrm{SiO} 2$ & $\begin{array}{l}20 \%- \\
25 \%\end{array}$ \\
\hline $\mathrm{Al} 2 \mathrm{O} 3$ & $7 \%-12 \%$ \\
\hline $\mathrm{Fe} 2 \mathrm{O} 3$ & $7 \%-12 \%$ \\
\hline $\mathrm{CaO}$ & $\begin{array}{l}60 \%- \\
65 \%\end{array}$ \\
\hline
\end{tabular}

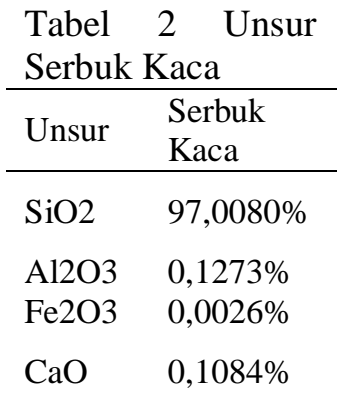

Umum

Batako merupakan bahan bangunan yang berupa bata cetak alternatif pengganti batu bata yang tersusun dari komposisi antara pasir, semen portland dan air dengan perbandingan 1 semen : 7 pasir. Batako difokuskan sebagai konstruksi-konstruksi dinding bangunan non struktural.

Batako yang baik adalah yang masingmasing permukaannya rata dan saling tegak lurus serta mempunyai kuat tekan yang tinggi. Persyaratan batako menurut Persyaratan Umum Bahan Bangunan di Indonesia 1982 (PUBI-1982) pasal 6 antara lain adalah berumur minimal satu bulan, pada waktu pemasangan harus sudah kering, berukuran panjang $\pm 400 \mathrm{~mm}$, lebar $\pm 200 \mathrm{~mm}$, tebal $\pm 100-200 \mathrm{~mm}$, kadar air $25-35 \%$ dari berat, dan memiliki kuat tekan antara 2-7 N/mm². Berdasarkan persyaratan fisik batako standar dalam PUBI-1982 memberikan batasan standar bahwa untuk batako dengan nilai kuat tekan 2-3,5 MPa dapat dipakai pada konstruksi yang tidak memikul beban. Untuk kuat tekan $2 \mathrm{MPa}$ dapat dipasang pada tempat yang terlindung dari cuaca luar dan diberi lapisan pelindung.

Menurut PUBI-1982 pasal 6, "Batako adalah bata yang dibuat dengan mencetak dan memelihara dalam kondisi lembab". Menurut SNI 03-0349-1989, "Conblock (concrete block) atau batu cetak beton adalah komponen bangunan yang dibuat dari campuran semen portland atau pozolan, pasir, air dan atau tanpa bahan tambahan lainnya (additive), dicetak sedemikian rupa hingga memenuhi syarat dan 
dapat digunakan sebagai bahan untuk pasangan dinding".

\section{Serbuk Kaca}

Kaca adalah salah satu produk industri kimia yang merupakan gabungan dari berbagai oksida anorganik yang tidak mudah menguap, yang dihasilkan dari dekomposisi dan peleburan senyawa alkali dan alkali tanah, pasir serta berbagai penyusun lainnya (Dian, 2011 dalam Wibowo, 2013).

- Penggunaan Kaca dalam Bidang Konstruksi

Kaca adalah salah satu produk industri kimia yang paling akrab dengan kehidupan kita sehari-hari. Dipandang dari segi fisika, kaca merupakan zat cair yang sangat dingin. Disebut demikian karena struktur partikel-partikel penyusunnya yang saling berjauhan seperti dalam zat cair, namun kaca sendiri berwujud padat. Ini terjadi akibat proses pendinginan (cooling) yang sangat cepat, sehingga partikel-partikel silika tidak sempat menyusun diri secara teratur. Kaca merupakan hasil penguraian senyawa-senyawa organik yang mana telah mengalami pendinginan tanpa kristalisasi. Unsur pokok dari kaca adalah silika (Setiawan, 2006). Kaca memiliki sifat-sifat yang khas dibanding dengan golongan keramik lainnya. Sifat sifat kaca ini terutama dipengaruhi oleh keunikan silica $\left(\mathrm{SiO}_{2}\right)$ dan proses pembentukannya.

Beberapa sifat-sifat kaca secara umum adalah:

- $\quad$ Padatan amorf (short range order);

- Berwujud padat tapi susunan atomatomnya seperti pada zat cair;

- Tidak memiliki titik lebur yang pasti ada range tertentu);

- Transparan, tahan terhadap serangan kimia, kecuali hidrogen fluorida.
Karena itulah kaca banyak dipakai untuk peralatan laboratorium;

- Efektif sebagai isolator;

- Mampu menahan vakum tetapi rapuh terhadap benturan.

Kaca memiliki sifat-sifat yang khas dibanding dengan golongan keramik lainnya. Kekhasan sifat-sifat kaca ini terutama dipengaruhi oleh keunikan silika $\left(\mathrm{SiO}_{2}\right)$ dan proses pembentukannya. Reaksi yang terjadi dalam pembuatan kaca secara ringkas pada persamaan dibawah ini (Dian, 2011 dalam Wibowo, 2013):

$$
\begin{array}{lll}
\mathrm{Na}_{2} \mathrm{CO}_{3}+\mathrm{a} \cdot \mathrm{SiO}_{2} & \longrightarrow & \mathrm{Na}_{2} \mathrm{O} \cdot \mathrm{aSiO}_{2} \\
& +\mathrm{CO}_{2} \\
\mathrm{CaCO}_{3}+\text { b. } & \mathrm{SiO}_{2} & \mathrm{CaO} \cdot \mathrm{bSiO} \\
& & \mathrm{CO}_{2} \\
\mathrm{Na}_{2} \mathrm{SO}_{4}+\text { c. } . \mathrm{SiO}_{2}+\mathrm{C} \longrightarrow & \mathrm{Na}_{2} \mathrm{O} \cdot \mathrm{cSiO} \\
& +\mathrm{SO}_{2}+\mathrm{SO}_{2} \\
& +\mathrm{CO}
\end{array}
$$

Bubuk kaca mempunyai kelebihan dibandingkan dengan bahan pengisi pori yang lainnya (Dian, 2011 dalam Wibowo, 2013), yaitu:

- Mempunyai sifat tidak menyerap air (zero water absorption),

- Kekerasan dari gelas menjadikan beton tahan terhadap abrasi yang hanya dapat dicapai oleh sedikit agregat alami,

- Bubuk kaca/serbuk kaca memperbaiki kandungan dari beton segar sehingga kekuatan yang tinggi dapat dicapai tanpa penggunaan superplasticizer,

- Bubuk kaca/serbuk kaca yang baik mempunyai sifat pozzoland sehingga dapat berfungsi sebagai pengganti semen dan filler.

- Kandungan dalam Kaca

Ada beberapa kandungan kaca berdasarkan jenis-jenis kaca, yaitu: clear glass, amber glass, green glass, pyrex glass, dan fused silica (Setiawan, 2006). Kandungan di dalam jenis-jenis kaca tersebut akan dijelaskan pada Tabel 3 seperti berikut ini.

Tabel 3 Kandungan Kaca dalam Persen

\begin{tabular}{cccccc}
\hline Jenis Kaca & Clear Glass & Amber Glass & Green Glass & Pyrex Glass & Fused Silica \\
\hline $\mathrm{SiO}_{2}$ & $73,2-73,5$ & $71,0-72,4$ & 71,27 & 81 & 99,87 \\
$\mathrm{Al}_{2} \mathrm{O}_{3}$ & $1,7-1,9$ & $1,7-1,8$ & 2,22 & 2 & - \\
$\mathrm{Na}_{2} \mathrm{O}+\mathrm{K}_{2} \mathrm{O}$ & $13,6-14,1$ & $13,8-14,4$ & 13,06 & 4 & - \\
$\mathrm{CaO}+\mathrm{MgO}$ & $10,7-10,8$ & 11,6 & 12,17 & - & - \\
$\mathrm{SO}_{3}$ & $0,2-0,24$ & $0,12-0,14$ & 0,052 & - & - \\
$\mathrm{Fe}_{2} \mathrm{O}_{3}$ & $0,04-0,05$ & 0,3 & 0,599 & 3,72 & - \\
$\mathrm{Cr}_{2} \mathrm{O}_{3}$ & - & 0,01 & 0,43 & $12,0-13,0$ & - \\
\hline
\end{tabular}


Kandungan kimia di dalam bubuk kaca didapat dari pengujian di Laboratorium FMIPA Kimia Universitas Sumatera Utara dengan hasil seperti terdapat pada Tabel 4.

Tabel 4. Kandungan Serbuk Kaca

\begin{tabular}{cc}
\hline Unsur & Serbuk Kaca \\
\hline $\mathrm{SiO} 2$ & $91,0080 \%$ \\
$\mathrm{~A} 2 \mathrm{O} 3$ & $0,1273 \%$ \\
$\mathrm{Fe} 2 \mathrm{O} 3$ & $0,0026 \%$ \\
$\mathrm{CaO}$ & $0,1084 \%$ \\
\hline
\end{tabular}

- $\quad$ Pengaruh Sifat Reaktif Silika pada Kaca Penggunaan agregat halus kaca yang dibuat dari jenis kaca leburan soda lime, mulai dikembangkan untuk membuat beton kinerja tinggi. Agregat halus kaca ini dibuat dalam bentuk bubuk dengan ukuran dan distribusi yang serupa agregat halus/pasir alam. Penggunaannya diharapkan dapat memanfaatkan limbah dari hasil samping industri untuk komponen industri konstruksi dan untuk mengatasi kekurangan pasir alam yang tersedia. Berdasarkan ASTM C289-87 dilakukan tes kimia dan tes kereaktifan agregat didapat bahwa bubuk kaca masih layak digunakan sebagai agregat walaupun memiliki sifat "merugikan" karena mengandung silika reaktif yang dapat bereaksi dengan alkali semen, sehingga mengakibatkan terjadinya ekspansi beton (Noor, 1995 dalam Wibowo, 2013).

Pada penelitian ini, bahan kaca yang dipakai untuk batako adalah serbuk kaca dari berbagai jenis botol minuman bekas yang termasuk pada golongan kaca soda gamping.

Tujuan dilakukannya penelitian ini:

- Mengetahui variasi komposisi campuran serbuk kaca untuk campuran batako.

- Mutu batako yang dihasilkan variasi komposisi campuran serbuk kaca yang optimal sesuai SNI.

Manfaat yang diharapkan akan dihasilkan dari penelitian ini adalah penggunaan serbuk kaca untuk dimanfaatkan pada pembuatan batako agar menghasilkan batako varian baru yaitu batako yang memiliki kualitas tinggi dibandingkan bata konvensional terutama pada kuat tekan dan daya serap air sehingga memberikan kenyamanan lebih pada penghuni bangunan. Optimasi komposisi serbuk kaca diharapkan dapat memberikan nilai ekonomis sehingga dapat diterapkan pada Industri Kecil Menengah, dengan memperhatikan kajian tekno ekonomis untuk melihat kelayakan untuk dikelola secara komersial.

\section{METODE PENELITIAN}

Metode yang digunakan dalam penelitian ini adalah metode penelitian eksperimen. Sedangkan faktor yang diteliti adalah faktor komposisi campuran serbuk kaca pada batako, dengan tujuan untuk mengetahui pengaruh serbuk kaca sebagai bahan tambah dengan mengurangi jumlah semen pada ukuran, daya serap air, kuat tekan dan kuat tarik. Rancangan penelitian pada batako akan dibuat benda uji dengan perbandingan campuran $1 \mathrm{Pc}: 7 \mathrm{Ps}$, dimana campuran ini akan diberi serbuk kaca sebagai bahan substitusi dengan mengurangi jumlah persentase dari berat semen dengan variasi perbandingan komposisi yang digunakan berdasarkan atas kategori perbandingan volume dari agregat penyusun batako, yaitu $0 \%, 10 \%, 15 \%, 20 \%, 25 \%$ dan $30 \%$ serbuk kaca dari berat semen. Dengan 2 variasi ukuran butiran kaca, yakni : 1. Butiran kaca dengan Ø lolos ayakan no. 200 dan 2. Butiran kaca dengan $\varnothing$ lolos ayakan no. 100 dan tertahan di ayakan no. 200. Pembuatan benda uji dan prosedur pengujian kualitas sesuai dengan yang telah ditentukan dalam Standar Nasional Indonesia (SNI 03-03491989).

\section{Bahan yang Digunakan}

- Semen Portland, Semen Portland yang dipergunakan adalah semen type 1 dengan merk dagang Semen Padang dalam kemasan $50 \mathrm{~kg}$.

- Pasir, Pasir yang dipergunakan dalam penelitian ini diambil dari quarry Sei Wampu, Binjai.

- Air, Air yang digunakan sebagai bahan pencampur berasal dari Laboratorium Bahan Rekayasa Departemen Teknik Sipil Fakultas Teknik Universitas Sumatera Utara.

- Serbuk Kaca, Pada penelitian ini, bahan kaca yang dipakai untuk batako berasal dari berbagai jenis botol minuman bekas yang dihancurkan di Laboratorium Bahan 
Rekayasa Departemen Teknik Sipil Fakultas Teknik Universitas Sumatera Utara dan di ayak dengan ayakan No.100 dan No.200.

\section{Persiapan benda uji}

Pemeriksaan material, antara lain:

- Pemeriksaan berat jenis semen

- Pemeriksaan gradasi butiran agregat

- Pemeriksaan kadar lumpur

- Pemeriksaan kandungan organik

- Pemeriksaan kadar liat

- Pemeriksaan berat isi agregat

- Pemeriksaan berat jenis agregat

Pembuatan Serbuk Kaca dengan Los Angeles Pada penelitian ini, untuk mendapatkan serbuk kaca yang ukuran butirannya halus dan lolos ayakan No.100 dan No. 200, dilakukan dengan menggunakan mesin Los Angeles. Adapun alat dan bahan serta langkah-langkah pengerjaannya adalah sebagai berikut:

- Alat dan Bahan:

- Mesin Los Angeles

- Peluru pengaus

- Ayakan No. 200

- Botol-botol kaca

Prosedur pengerjaan:

- Bersihkan botol-botol kaca dari sisa-sisa kotoran;

- Masukkan peluru pengaus dan botol-botol kaca yang telah dibersihkan tadi ke dalam mesin Los angeles;

- Tutup dan kunci mesin Los Angeles;

- Putar mesin \pm 45 menit;

- Sampel dikeluarkan dari mesin lalu di ayak dengan ayakan No. 100 dan No. 200

Pembuatan Benda Uji

- Peralatan yang diperlukan dalam pembuatan benda uji:

- Ayakan, untuk mengayak pasir dengan ukuran 4,8 $\mathrm{mm}$.

- Timbangan, untuk menimbang kebutuhan bahan yang dipergunakan dalam pembuatan benda uji.

- Ember, untuk tempat menampung kebutuhan air yang dipergunakan sebagai pencampuran bahan-bahan pembuat.

- Sendok spesi, untuk mencampur dan memasukkan adonan adukan kedalam cetakan.

- Sekop dan cangkul.

- Mesin molen.

- Batang perojok atau vibrator, untuk memadatkan adukan di dalam cetakan.

- Cetakan batako terbuat dari plat besi berbentuk balok dengan ukuran cetakan adalah $400 \times 200$ x $100 \mathrm{~mm}$.

- Cetakan kubus, terbuat dari besi berbentuk kubus dengan ukuran $15 \times 15 \times 15 \mathrm{~cm}$.

- Cetakan/mould briquette, terbuat dari besi berbentuk angka delapan dengan ukuran $7,5 \mathrm{x}$ $4,15 \times 2,5 \mathrm{~cm}$

- Prosedur Pembuatan benda uji :

- Siapkan semua bahan dan alat yang diperlukan.

- Timbang semen, pasir dan serbuk kaca dengan perbandingan 1 pc : 7 ps. Penambahan serbuk kaca dimulai dari $0 \%, 10 \%, 15 \%$, $20 \%, 25 \%$ dan $30 \%$ dari berat semen dengan mengurangi jumlah semen awal. Dengan 2 variasi ukuran butiran kaca. Yaitu butiran lolos ayakan no. 200 dan butiran yang lolos ayakan no. 100 dan tertahan di ayakan no. 200.

- Campurkan bahan dengan perbandingan menjadi $1 \mathrm{pc}: 7 \mathrm{ps}$ (tanpa penambahan serbuk kaca), untuk campuran selanjutnya dengan penambahan $10 \%, 15 \%, 20 \%, 25 \%$ dan $30 \%$. Aduk semua bahan sampai rata.

- Adonan batako yang sudah dicampur hingga rata ditambah air secukupnya sampai tercapai campuran setengah basah (lengas tanah) yang merata. Secara sederhana, keadaan ini dapat diketahui dengan cara: campuran yang telah merata dikepal dengan telapak tangan. 
Kemudian dijatuhkan dari ketinggian lebih kurang lebih kurang 1,2 meter kepermukaan tanah keras. Bila campuran sudah baik, $2 / 3$ bagian tetap mengumpul dan $1 / 3$ lainnya tersebar (Utomo, 2010).

- Sebelum dimasukkan ke dalam cetakan, adonan yang sudah tercampur merata dituangkan sebagian ke dalam sebuah pan besar yang tidak menyerap air.

- Masukkan adonan batako kedalam cetakan setinggi $2 / 3$ bagian cetakan, kemudian dipadatkan dengan cara ditumbuk sampai benar-benar padat dengan alat pemadat.

- Masukan kembali adonan batako kedalam cetakan hingga penuh, kemudian dipadatkan lagi.

Perawatan Benda Uji Batako

- Hindarkan batako dari sinar matahari langsung dan air hujan agar pengikatan adonan sesuai yang diharapkan.

- Perawatan batako selama 28 hari yaitu dengan menyiram dengan air setiap pagi dan sore hari.

Perawatan Benda Uji Kubus

Sama dengan perawatan beton, perawatan ini dilakukan setelah benda uji mencapai final setting (mengeras). Perawatan ini dilakukan agar proses hydrasi selanjutnya tidak mengalami gangguan. Jika hal ini terjadi, beton akan mengalami keretakan karena kehilangan air yang begitu cepat (Mulyono, 2003).

Pada penelitian ini, perawatan benda uji kubus dilakukan dengan cara merendam benda uji di bak perendaman khusus di Laboratorium Bahan Rekayasa Departemen Teknik Sipil Fakultas Teknik Universitas Sumatera Utara.

\section{Perawatan Benda Uji Briquette}

Perawatan benda uji briquette sama halnya dengan perawatan benda uji kubus, yaitu benda uji direndam di bak perendaman khusus di Laboratorium Bahan Rekayasa Departemen Teknik Sipil Fakultas Teknik Universitas Sumatera Utara.

\section{Pengujian Benda Uji}

Pengujian Visual

- Peralatan yang diperlukan pada pemeriksaan tampak luar:

Penggaris siku dipergunakan untuk memeriksa kesikuan pada tiap-tiap sudut dan kedataran permukaan bidang dari batako pejal. Selebihnya pemeriksaan tampak luar dilakukan dengan menggunakan alat indra, seperti pemeriksaan pada ketajaman dan kekuatan rusuk-rusuk batako tidak mudah dirapihkan dengan kekuatan jarijari tangan.

- Peralatan yang diperlukan pada pemeriksaan ukuran:

Kaliper atau mistar sorong, dipergunakan untuk mengukur dimensi batako. Kaliper yang dipergunakan sampai dengan ketelitian 0,01 mm.

- Prosedur Pengujian:

Setelah masa perawatan selama 28 hari, batako yang diuji harus dalam keadaan kering. Tahapan yang harus dilakukan yaitu:

- Bersihkan permukaan benda uji batako dari berbagai kotoran yang menempel.

- Ukur panjang, lebar dan tebal benda uji.

- Pengamatan permukaan benda uji meliputi: keadaan permukaan, kerapatan dan keadaan sudutsudutnya.

\section{Pengujian Penyerapan Air}

- Peralatan yang diperlukan pada pengujian penyerapan air:

- Wadah berisi air untuk merendam benda uji hingga batako jenuh air.

- Kain lap dipergunakan untuk menyeka permukaan batako dari kelebihan air setelah di rendam.

- Timbangan dipergunakan untuk menimbang batako dalam keadaan jenuh air dan kering oven. Timbangan yang dipergunakan dengan kapasitas $60 \mathrm{~kg}$ dengan ketelitian $0,1 \mathrm{gr}$.

- Oven dipergunakan untuk mengeringkan batako akan kandungan air setelah direndam. 
Oven yang dipergunakan
dilengkapi pengatur suhu,
dengan suhu antara $105^{\circ} \mathrm{C}$
sampai dengan $110^{\circ} \mathrm{C}$.

- Prosedur Pengujian:

Batako yang akan diuji penyerapan airnya harus dalam keadaan kering. Adapun langkahlangkah yang harus dilakukan dalam pengujian ini adalah:

- Batako dibersihkan dari bahanbahan lain yang menempel.

- Batako dimasukan kedalam oven selama $24 \mathrm{jam} / \mathrm{sehari}$, sehingga didapati batako dalam kering oven.

- Timbang batako, sehingga didapat berat batako dalam keadaan kering oven.

- Rendam batako selama 24 jam /sehari atau hingga batako sudah keadaan jenuh.

- Timbang batako, sehingga didapati berat batako dalam keadaan jenuh. Setelah mendapatkan data-data yang diperlukan, penyerapan air dapat dihitung.

\section{Pengujian Kuat Tekan}

- Peralatan yang diperlukan pada pengujian kuat tekan:

- Timbangan dipergunakan untuk menimbang benda uji.

- Mistar sorong dipergunakan untuk mengukur luas bidang tekan. Mistar sorong dipergunakan sampai dengan ketelitian 0,01 mm.

- Alat uji yang digunakan adalah mesin uji kuat tekan beton (compression machine).

- Prosedur Pengujian:

- Benda uji dikeluarkan dari bak perendaman, lalu dijemur selama \pm 24 jam.

- Timbang berat benda uji lalu letakkan pada compressor machine sedemikian sehingga berada tepat ditengah-tengah alat penekannya.

- Secara perlahan-perlahan beban tekan diberikan pada benda uji dengan cara mengoperasikan mesin sampai benda uji runtuh.

- Pada saat jarum penunjuk skala tidak naik lagi atau bertambah, maka catat skala yang ditunjuk oleh jarum tersebut yang merupakan beban maksimum yang dapat dipikul benda uji tersebut.

- Percobaan diulang untuk setiap benda uji.

- Hitung kuat tekan batako.

\section{Pengujian Kuat Tarik}

- Peralatan yang diperlukan pada pengujian kuat tarik:

- Timbangan dipergunakan untuk menimbang benda uji.

- Mistar sorong dipergunakan untuk mengukur luas bidang tarik. Mistar sorong dipergunakan sampai dengan ketelitian $0,01 \mathrm{~mm}$.

- Alat uji yang digunakan adalah mesin uji kuat tarik briquette (tensile test machine).

- Prosedur Pengujian:

- Benda uji briquette yang telah direndam dikeluarkan 24 jam sebelum pengujian dilakukan dan dikeringkan dengan kain lap, lalu dibiarkan selama 24 jam.

- Timbang berat benda uji.

- Siapkan alat tensile test dan masukkan benda uji kedalam penjepit yang ada pada alat tensile test, kemudian kencangkan dengan memutar alat pengunci.

- Stel skala penunjuk pada angka nol dan hidupkan alat tensile test.

- Matikan alat begitu benda uji patah.

- Catat pembacaan pada skala penunjuk, besar gaya tarik adalah hasil pembacaan dikalikan scale reading

- Ukur luas patahan dengan jangka sorong

- Hitung kuat tarik briquette. 


\section{HASIL DAN PEMBAHASAN}

Berdasarkan hasil pengujian yang dilakukan di laboratorium, maka di dalam bab ini akan disajikan data-data hasil pengujian beserta analisa data tersebut. Adapun data yang tersedia meliputi data pengujian kuat tekan, pengujian penyerapan air, pengujian kuat tarik brequette, dan analisa penyimpangan ukuran batako.

\section{Pengujian Kuat Tekan}

Benda uji yang digunakan adalah yang telah berumur 28 hari perawatan dengan dua variasi penambahan serbuk kaca yaitu, serbuk kaca lolos ayakan $\varnothing 100-\varnothing 200$ dan serbuk kaca lolos ayakan $\varnothing 200$. Dimana spesimen merupakan kubus yang diambil ketika proses pengecoran dan diberi tekanan sampai diperoleh beban maksimum yang mampu ditahan oleh kubus tersebut. Hasil pengujian dapat dilihat pada Tabel 5, Tabel 6, dan Gambar 1.

Tabel 5. Hasil Pengujian Kuat Tekan dengan Penambahan Serbuk Kaca Lolos Ayakan

\begin{tabular}{|c|c|c|c|c|}
\hline & & $100-\varnothing 20$ & & \\
\hline $\begin{array}{l}\mathrm{N} \\
\mathrm{O}\end{array}$ & $\begin{array}{c}\text { Penambaha } \\
\text { n Serbuk } \\
\text { Kaca }\end{array}$ & $\begin{array}{c}\text { Pembacaa } \\
\text { n Dial } \\
\text { Rata-rata } \\
(\mathrm{kN})\end{array}$ & $\begin{array}{c}\text { Luas } \\
(\mathrm{mm} 2 \\
)\end{array}$ & $\begin{array}{c}\text { Kuat } \\
\text { Tekan } \\
\text { Rata- } \\
\text { rata } \\
(\mathrm{kg} / \mathrm{cm} 2 \\
\quad)\end{array}$ \\
\hline 1 & $0 \%$ & 214,4 & 2250 & 95,289 \\
\hline 2 & $10 \%$ & 145 & 2250 & 64,444 \\
\hline 3 & $15 \%$ & 157 & 2250 & 69,778 \\
\hline 4 & $20 \%$ & 168,8 & 2250 & 75,022 \\
\hline 5 & $25 \%$ & 151,2 & 2250 & 67,2 \\
\hline 6 & $30 \%$ & 123,4 & 2250 & 54,844 \\
\hline
\end{tabular}

http://ejournal.umm.ac.id/index.php/jmts/article/view/3292

Tabel 6 Hasil Pengujian Kuat Tekan dengan Penambahan Serbuk Kaca Lolos Ayakan $\varnothing 200$

\begin{tabular}{ccccc}
\hline & Penambaha & $\begin{array}{c}\text { Pembacaa } \\
\text { n Dial } \\
\text { n Serbuk } \\
\text { Kaca }\end{array}$ & $\begin{array}{c}\text { Luas } \\
(\mathrm{kN})\end{array}$ & $\begin{array}{c}\text { Kuat } \\
\text { Tekan } \\
\text { Rata- } \\
\text { rata }\end{array}$ \\
& & & & $\begin{array}{c}\text { (kg/cm2 } \\
)\end{array}$ \\
\hline 1 & $0 \%$ & 214,4 & 2250 & 95,289 \\
2 & $10 \%$ & 168,6 & 2250 & 74,933 \\
3 & $15 \%$ & 176,6 & 2250 & 78,489 \\
4 & $20 \%$ & 206,6 & 2250 & 91,822 \\
5 & $25 \%$ & 200,8 & 2250 & 89,244 \\
6 & $30 \%$ & 174,4 & 2250 & 77,511 \\
\hline
\end{tabular}

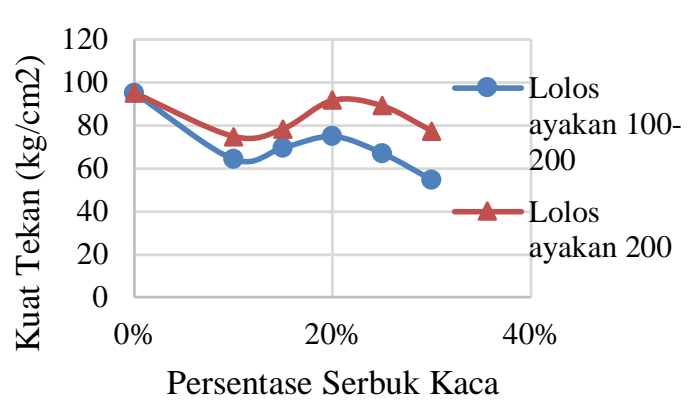

Gambar 1. Grafik Kuat Tekan dengan Penambahan Serbuk Kaca Lolos Ayakan $\varnothing 100-\varnothing 200$ dan Lolos Ayakan $\varnothing 200$

Berdasarkan data di atas, benda uji dapat dilihat kualitas mutunya berdasarkan SNI 030349-1989, Tabel 7.

Tabel 7. Syarat-Syarat Fisis Bata Beton Berdasarkan SNI 03-0349-1989

\begin{tabular}{llllllllll}
\hline Syarat Fisik & Satuan & \multicolumn{8}{c}{ Tingkat Mutu } \\
& & \multicolumn{9}{c}{ Bata Beton Pejal } & \multicolumn{3}{c}{ Bata Beton Berlobang } \\
& & I & II & III & IV & I & II & III & IV \\
\hline $\begin{array}{l}\text { Kuat tekan bruto } \\
\text { rata-rata minimum }\end{array}$ & $\mathrm{kg} / \mathrm{cm} 2$ & 100 & 70 & 40 & 25 & 70 & 50 & 35 & 20 \\
$\begin{array}{l}\text { Kuat tekan bruto1) } \\
\text { benda uji min }\end{array}$ & $\mathrm{kg} / \mathrm{cm} 2$ & 90 & 65 & 35 & 21 & 65 & 45 & 30 & 17 \\
$\begin{array}{l}\text { Penyerapan air rata- } \\
\text { rata maks. }\end{array}$ & $\mathrm{kg} / \mathrm{cm} 2$ & 25 & 35 & - & - & 25 & 35 & - & - \\
\hline
\end{tabular}

Catatan:

1) Kuat tekan bruto adalah beban tekan keseluruhan pada waktu benda uji pecah dibagi dengan luas ukurannya dari permukaan bata yang tertekan, termasuk luas lobang serta cekungan tepi

2) Tingkat Mutu:

Tingkat I : Untuk dinding struktural tidak terlindungi

Tingkat II: Untuk dinding struktural terlindungi (boleh ada beban)

Tingkat III : Untuk dinding non struktural tak terlindungi boleh terkena hujan dan panas

Tingkat IV : Untuk dinding non struktural terlindungi dari cuaca 


\section{Pengujian Kuat Tarik}

Pengujian untuk kuat tarik digunakan benda uji berbentuk briquette dimana spesimen diambil ketika proses pengecoran dan diberikan pembebanan maksimum sampai benda uji patah. Benda uji yang sudah berumur 28 hari dengan dua variasi penambahan serbuk kaca yaitu, serbuk kaca lolos ayakan $\varnothing 100-\varnothing 200$ dan serbuk kaca lolos ayakan $\varnothing 200$. Hasil pengujian dapat dilihat pada Tabel 8., Tabel 9, dan Gambar 2.

Tabel 8. Hasil Pengujian Kuat Tarik dengan Penambahan Serbuk Kaca Lolos Ayakan

\begin{tabular}{ccc}
\multicolumn{3}{c}{$\varnothing 100-\varnothing 200$} \\
\hline \multirow{2}{*}{ No } & $\begin{array}{c}\text { Penambahan } \\
\text { Serbuk Kaca }\end{array}$ & $\begin{array}{c}\text { Kuat Tarik } \\
\text { Rata-rata }(\mathrm{kg} / \mathrm{cm} 2)\end{array}$ \\
\hline 1 & $0 \%$ & 16,268 \\
2 & $10 \%$ & 16,098 \\
3 & $15 \%$ & 19,464 \\
4 & $20 \%$ & 17,465 \\
5 & $25 \%$ & 14,356 \\
6 & $30 \%$ & 14,205 \\
\hline
\end{tabular}

Tabel 9. Hasil Pengujian Kuat Tarik dengan Penambahan Serbuk Kaca Lolos Ayakan

\begin{tabular}{ccc}
\multicolumn{2}{c}{$\varnothing 200$} \\
\hline \multirow{2}{*}{ No } & $\begin{array}{c}\text { Penambahan } \\
\text { Serbuk Kaca }\end{array}$ & $\begin{array}{c}\text { Kuat Tarik } \\
\text { Rata-rata }(\mathrm{kg} / \mathrm{cm} 2)\end{array}$ \\
\hline 1 & $0 \%$ & 16,268 \\
2 & $10 \%$ & 16,068 \\
3 & $15 \%$ & 16,871 \\
4 & $20 \%$ & 17,398 \\
5 & $25 \%$ & 17,75 \\
6 & $30 \%$ & 16,763 \\
\hline
\end{tabular}

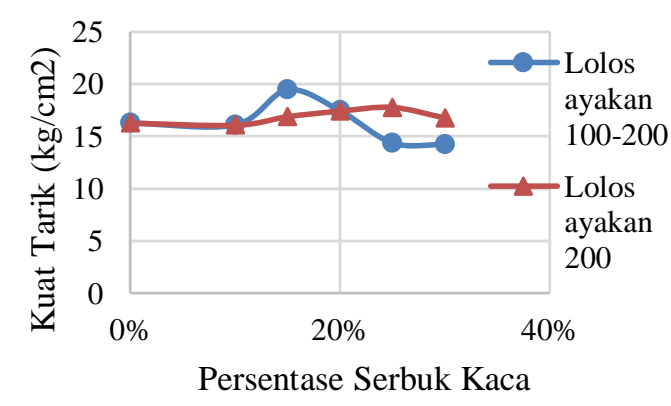

Gambar 2. Grafik Kuat Tarik dengan Penambahan Serbuk Kaca Lolos Ayakan $\varnothing 100-\varnothing 200$ dan Lolos Ayakan $\varnothing 200$

\section{Pengujian Absorbsi}

Benda uji yang dipakai untuk pengujian absorbsi adalah benda uji dengan ukuran 10 x 20 x $40 \mathrm{~cm}$ sebagaimana ukuran batako pada umumnya. Benda uji yang telah berumur 28 hari kemudian di rendam selama 24 jam, kemudian ditimbang untuk mendapat berat saat basah. Selanjutnya batako di oven selama 24 jam untuk mendapat berat saat kering. Hasil pengujian dapat dilihat pada Tabel 5.6, Tabel 5.7, dan Grafik 5.3.

Tabel 10. Hasil Pengujian Absorbsi dengan Penambahan Serbuk Kaca Lolos Ayakan

\begin{tabular}{ccccc}
\multicolumn{5}{c}{$\varnothing 100-\varnothing 200$} \\
\hline N & $\begin{array}{c}\text { Penam } \\
\text { bahan } \\
\text { Serbuk } \\
\text { Kaca }\end{array}$ & $\begin{array}{c}\text { Berat } \\
\text { Rata- } \\
\text { rata } \\
\text { Basah } \\
(\mathrm{kg})\end{array}$ & $\begin{array}{c}\text { Berat } \\
\text { Rata- } \\
\text { rata } \\
\text { Kering } \\
(\mathrm{kg})\end{array}$ & $\begin{array}{c}\text { Penyerapa } \\
\text { n Air } \\
\text { Rata-rata } \\
(\%)\end{array}$ \\
\hline 1 & $0 \%$ & 19,5826 & 18,9882 & 3,133 \\
2 & $10 \%$ & 19,7009 & 19,0749 & 3,282 \\
3 & $15 \%$ & 18,3892 & 17,782 & 3,421 \\
4 & $20 \%$ & 18,9479 & 18,111 & 4,623 \\
5 & $25 \%$ & 17,8388 & 16,9498 & 5,362 \\
6 & $30 \%$ & 18,1732 & 17,2362 & 5,459 \\
\hline
\end{tabular}

Tabel 11. Hasil Pengujian Absorbsi dengan Penambahan Serbuk Kaca Lolos Ayakan

\begin{tabular}{ccccc}
\multicolumn{5}{c}{$\phi 200$} \\
No & $\begin{array}{c}\text { Penam } \\
\text { bahan } \\
\text { Serbuk } \\
\text { Kaca }\end{array}$ & $\begin{array}{c}\text { Berat } \\
\text { Rata- } \\
\text { rata } \\
\text { Basah } \\
(\mathrm{kg})\end{array}$ & $\begin{array}{c}\text { Berat } \\
\text { Rata- } \\
\text { rata } \\
\text { Kering } \\
(\mathrm{kg})\end{array}$ & $\begin{array}{c}\text { Penyerapan } \\
\text { Air Rata- } \\
\text { rata (\%) }\end{array}$ \\
\hline 1 & $0 \%$ & 19,5826 & 18,9882 & 3,133 \\
2 & $10 \%$ & 18,7913 & 18,1176 & 3,718 \\
3 & $15 \%$ & 18,2134 & 17,4089 & 4,642 \\
4 & $20 \%$ & 17,7855 & 16,9188 & 5,123 \\
5 & $25 \%$ & 18,1853 & 17,229 & 5,541 \\
6 & $30 \%$ & 17,9522 & 16,9654 & 5,813 \\
\hline
\end{tabular}

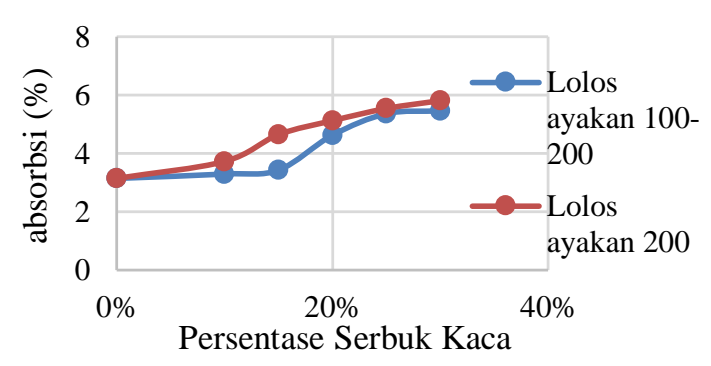

Gambar 3. Grafik Absorbsi dengan Penambahan Serbuk Kaca Lolos Ayakan $\varnothing 100-\varnothing 200$ dan Lolos Ayakan $\varnothing 200$ 


\section{Pengujian Viaual}

\section{Pemeriksaan Tampak Luar}

Tabel 12. Perbandingan Hasil Pemeriksaan Visual dengan Syarat Mutu

\begin{tabular}{lccccccc}
\hline \multicolumn{1}{c}{ Uraian } & \multicolumn{9}{c}{ Rata-rata keadaan sampel } \\
& BSK & BSK & BSK & BSK & BSK & BSK & SNI 03- \\
& $0 \%$ & $10 \%$ & $15 \%$ & $20 \%$ & $25 \%$ & $30 \%$ & \\
\hline 1. Bidang-bidang & & & & & & & \\
a. Kerataan & Rata & Rata & Rata & Rata & Rata & Rata & Rata \\
b. Keretakan & Tidak & Tidak & Tidak & Tidak & Tidak & Tidak & Tidak Retak \\
& Retak & Retak & Retak & Retak & Retak & Retak & \\
c. Kehalusan & Halus & Halus & Halus & Halus & Halus & Halus & Halus \\
& & & & & & & \\
2. Rusuk-rusuk & & & & & & & \\
a. Kesikuan & Siku & Siku & Siku & Siku & Siku & Siku & Siku \\
b. Ketajaman & Tajam & Tajam & Tajam & Tajam & Tajam & Tajam & Tajam \\
c. Kekuatan & Kuat & Kuat & Kuat & Kuat & Kuat & Kuat & Kuat \\
\hline
\end{tabular}

Apabila meninjau Tabel 5.8, dari keenam komposisi campuran batako dengan penambahan serbuk kaca lolos ayakan $\varnothing 100$ $\varnothing 200$ dan lolos ayakan $\varnothing 200$ yang dicoba telah memenuhi syarat tampak luar menurut ketentuan dalam SNI 03-0349-1989, yaitu menghasilkan batako yang mempunyai permukaan bidang rata, tidak retak dan halus.

\section{Pemeriksaan Ukuran}

Setelah melakukan pemeriksaan dan didapat data pengukuran dimensi pada masing-masing komposisi batako, kemudian data tersebut harus di analisis penyimpangan ukurannya sesuai dengan ketentuan SNI. 0349-1989. Ukuran yang menjadi acuan sampel batako, sebagai berikut: panjang $=400$ $\mathrm{mm}$; lebar $=200 \mathrm{~mm}$; tebal $=100 \mathrm{~mm}$.

Berikut merupakan rekapitulasi hasil rata-rata pemeriksaan ukuran batako dari enam macam campuran yang dicoba, seperti pada tabel berikut:

Tabel 13. Perbandingan Penyimpangan Ukuran Rata-rata Batako Lolos Ayakan $\varnothing 100-\varnothing 200$ dengan Syarat Mutu

\begin{tabular}{ccccccc}
\hline \multirow{2}{*}{ Komposisi Campuran } & \multicolumn{2}{c}{ Panjang (mm) } & \multicolumn{2}{c}{ Lebar (mm) } & \multicolumn{2}{c}{ Tebal (mm) } \\
& Benda Uji & SNI 0349-89 & Benda Uji & SNI 0349-89 & Benda Uji & SNI 0349-89 \\
\hline BSK0\% & 1 & 5 & 0,8 & 2 & 1,4 & 2 \\
BSK10\% & 0,8 & 5 & 0,7 & 2 & 1,2 & 2 \\
BSK15\% & 0,9 & 5 & 0,8 & 2 & 0,9 & 2 \\
BSK20\% & 0,9 & 5 & 0,7 & 2 & 0,9 & 2 \\
BSK25\% & 0,7 & 5 & 0,9 & 2 & 1 & 2 \\
BSK30\% & 0,8 & 5 & 0,7 & 2 & 0,8 & 2 \\
\hline
\end{tabular}

Tabel 14. Perbandingan Penyimpangan Ukuran Rata-rata Batako Lolos Ayakan $\varnothing 200$ dengan Syarat Mutu

\begin{tabular}{ccccccc}
\hline \multirow{2}{*}{ Komposisi Campuran } & \multicolumn{2}{c}{ Panjang (mm) } & \multicolumn{2}{c}{ Lebar (mm) } & \multicolumn{2}{c}{ Tebal (mm) } \\
& Benda Uji & SNI 0349-89 & Benda Uji & SNI 0349-89 & Benda Uji & SNI 0349-89 \\
\hline BSK0\% & 0,9 & 5 & 0,6 & 2 & 1,3 & 2 \\
BSK10\% & 0,7 & 5 & 0,7 & 2 & 0,7 & 2 \\
BSK15\% & 0,7 & 5 & 0,9 & 2 & 0,7 & 2 \\
BSK20\% & 1,0 & 5 & 0,9 & 2 & 1,3 & 2 \\
BSK25\% & 0,8 & 5 & 1,2 & 2 & 1,1 & 2 \\
BSK30\% & 0,6 & 5 & 0,7 & 2 & 0,7 & 2 \\
\hline
\end{tabular}

Apabila meninjau Tabel 5.9 dan Tabel 5.10, batako telah memenuhi syarat ukuran sesuai dengan ketentuan dalam SNI 03-0349-
1989. Hal tersebut disebabkan karena serbuk kaca mempunyai butiran hampir sama dengan semen yaitu lolos saringan No. 100 dan 
saringan No. 200 sehingga bahan tambah serbuk kaca dapat mengisi rongga antar pasir yang menyebabkan batako menjadi lebih padat, permukaan bidang batako menjadi rata, dan tidak retak.

Ditinjau dari data hasil pengujian, tidak menunjukkan perbedaan yang signifikan. Kondisi tersebut dikarenakan cara pembuatan batako secara manual sehingga diperoleh batako dengan kepadatan yang tidak seragam. Karena kerapatan pori-pori yang terdapat didalam batako akan sangat berpengaruh pada kepadatan komposisi batako tersebut.

\section{KESIMPULAN DAN SARAN}

\section{Kesimpulan}

Dari hasil penelitian didapat kesimpulan sebagai berikut:

- Kuat tekan normal (0\%) tanpa substitusi serbuk kaca sebesar 95,289 $\mathrm{kg} / \mathrm{cm}^{2}$ dan masuk klasifikasi batako tingkat I. Kuat tekan maksimum dengan substitusi sebuk kaca $\varnothing$ Lolos Ayakan no.100-200 terdapat pada persentase $20 \%$ sebesar $75,022 \mathrm{~kg} / \mathrm{cm}^{2}$, termasuk dalam klasifikasi batako tingkat II dan kuat tekan minimum terdapat pada persentase $30 \%$ sebesar $54,844 \mathrm{~kg} / \mathrm{cm}^{2}$, termasuk klasifikasi batako tingakat III. Kuat tekan maksimum untuk substitusi sebuk kaca $\varnothing$ Lolos Ayakan no. 200 terdapat pada persentase $20 \%$ sebesar $91,822 \mathrm{~kg} / \mathrm{cm}^{2}$, termasuk dalam klasifikasi batako tingkat I dan kuat tekan minimum terdapat pada persentase $10 \%$ sebesar $74,933 \mathrm{~kg} / \mathrm{cm}^{2}$, termasuk klasifikasi batako tingkat II.

- Kuat tarik normal (0\%) tanpa substitusi serbuk kaca sebesar 16,268 kg/ $\mathrm{cm}^{2}$. Kuat tarik maksimum untuk substitusi sebuk kaca $\varnothing$ Lolos Ayakan no.100-200 terdapat pada persentase $15 \%$ sebesar $19,464 \mathrm{~kg} / \mathrm{cm}^{2}$ dan kuat tarik minimum terdapat pada persentase $30 \%$ sebesar $14,205 \mathrm{~kg} / \mathrm{cm}^{2}$. Kuat tarik maksimum untuk substitusi sebuk kaca $\varnothing$ Lolos Ayakan no. 200 terdapat pada persentase $25 \%$ sebesar $17,75 \mathrm{~kg} / \mathrm{cm}^{2}$ dan kuat tarik minimum terdapat pada persentase $10 \%$ sebesar $16,068 \mathrm{~kg} / \mathrm{cm}^{2}$.
- Penyerapan air (absorbsi) untuk batako normal (0\%) tanpa substitusi serbuk kaca sebesar 3,133\%. Penyerapan air (absorbsi) maksimum untuk batako dengan substitusi sebuk kaca $\varnothing$ Lolos Ayakan no.100-200 terdapat pada persentase $30 \%$ sebesar $5,495 \%$ dan absorbsi minimum terdapat pada persentase $10 \%$ sebesar $3,28 \%$. Penyerapan air (absorbsi) maksimum untuk batako dengan substitusi sebuk kaca $\varnothing$ Lolos Ayakan no. 200 terdapat pada persentase $30 \%$ sebesar 5,813\% dan absorbsi minimum terdapat pada persentase $10 \%$ sebesar $3,283 \%$.

- Semua sampel lolos klasifikasi batako tingkat I berdasarkan absorbsi yang lebih kecil dari $25 \%$. Hasil pengujian visual baik secara tampak maupun ukuran, semua sampel batako lolos klasifikasi SNI 03-0349-1989. Permukaan batako rata, halus dan tidak retak. Siku batako tajam, kuat, dan presisi. Penyimpangan ukuran yang terjadi masih dalam batasbatas ketentuan SNI 03-0349-1989.

\section{Saran}

Hasil penelitian yang dilakukan dapat menjadi acuan dalam menentukan alternatif pengganti semen dalam pembuatan batako. Dari penelitian ini dapat disarankan menggunakan serbuk kaca yang lolos ayakan $\varnothing 200$ sebanyak 20\% sebagai pengganti semen, dikarenakan hasil yang didapat sudah mendekati kekuatan batako normal dan mutu tingkat 1 menurut SNI 03-0349-1989. Namun masih perlu dilakukannya penelitian lanjutan untuk mengetahui durability dan kemampuan menahan beban struktur, serta pengembangan penelitian terhadap bobot yang diharapkan diperoleh bobot yang lebih ringan.

\section{DAFTAR PUSTAKA}

Chu-Kia Wang dan Salmon, Charles G. 1994. Disain Beton Bertulang. Jilid I. Edisi Keempat. Terjemahan Binsar Hariandja. Jakarta: Erlangga.

Departemen Pekerjaan Umum, 1982. Persyaratan Umum Bahan Bangunan di Indonesia, Pusat Penelitian dan Pengembangan Permukiman, Departemen Pekerjaan Umum, Bandung. 
Departemen P.U., 1989, SNI 03-0349-1989 Bata Beton untuk Pasangan Dinding, Balitbang, Jakarta.

Departemen P.U., 2004, SNI 15-2049-2004 Semen Portland, Balitbang, Jakarta.

Karwur, Handy Yohanes., Dkk. 2013. Kuat Tekan Beton Dengan Bahan Tambah Serbuk Kaca Sebagai Substitusi Parsial Semen. Jurnal Sipil Statik Vol. 1, 276281.

Kasiati, Endang. 2011. Pembuatan Paving Blok dengan Menggunakan Semen Portland dan Semen Pozzolan dengan Bahan Tambahan Serbuk Kaca dan Abu Batu. Seminar Nasional Aplikasi Teknologi Prasarana Wilayah 2011.

Latief, Abdul. 2010. Kuat Tarik Langsung, Kuat Tarik Lentur, Susut Dan Density Mortar Campuran Semen, Abu Sekam Padi, Dan Precious Slag Ball Dengan Persentase 30\%; 30\%; 40\%, Skripsi Program Studi Teknik Sipil Depok. Depok: UI.

Mulyono, Tri. 2004. Teknologi Beton. Yogyakarta: Penerbit Andi.

Setiawan, Budi. 2006. Pengaruh Penggunaan Agregat Kaca pada Beton Ditinjau dari Segi Kekuatan dan Shrinkage, Tugas Akhir Jurusan Teknik Sipil Universitas Kristen Petra. Surabaya.

Utomo, Hendratmo Muji. 2010. Analisis Kuat Tekan Batako dengan Limbah Karbit Sebagai Bahan Tambah, Tugas Akhir Program Studi Teknik Sipil Universitas Negeri Yogyakarta. Yogyakarta: UNY.

Wibowo, Levin. 2013. Pengaruh Penambahan Serbuk Kaca dan Water Reducing High Range Admixtures terhadap Kuat Desak dan Modulus Elastisitas pada Beton, Tugas Akhir Program Studi Teknik Sipil Universitas Atma Jaya Yogyakarta. Yogyakarta: UAJY. 